\title{
Waste Policy and European Community Law: Does the EEC Treaty Provide a Suitable Framework for Regulating Waste?
}

\author{
Jan H. Jans*
}

\section{INTRODUCTION}

European Economic Community (EEC) law on waste disposal is a complex field. Three sources of the complexity stand out: directives, treaty provisions, and case law.

First, there are many directives ${ }^{1}$ concerning waste, waste disposal, and waste transportation. The most important of these directives are:

- the Directive on Waste (Directive $75 / 442,{ }^{2}$ as amended by Directive $91 / 156^{3}$ ), containing general rules which, among other things, mandate that Member States take steps to ensure proper disposal, ${ }^{4}$ develop waste disposal plans, $^{5}$ and create permit programs; ${ }^{6}$

- the Directive on Toxic and Dangerous Waste (Directive 78/319), ${ }^{7}$ containing general rules which mandate that Member States take steps to ensure proper disposal, ${ }^{8}$ develop waste disposal plans, ${ }^{9}$ and create permit programs; ${ }^{10}$

Copyright (c) 1993 by ECology LAw QUARTERLY

* Professor of European Environmental Law, Centre for Environmental Law, University of Amsterdam; Ph.D. 1987, State University of Groningen, Netherlands; Advisor to Commissie voor de milieu-effectrapportage [Commission on Environmental Impact Assessment] and to Centrale raad voor de milieunygëine [Central Council on Environmental Hygiene].

1. Directives are statements of EEC policy, which Member States are allowed to implement in ways appropriate to that particular national system. They are binding only "as to the result to be achieved." TREATY ESTABlishing THE EUROPEAN ECONOMIC COMMUNITY [EEC TREATY] art. 189.

2. Council Directive 75/442, 1975 O.J. (L 194) 39.

3. Council Directive 91/156, 1991 O.J. (L 78) 32.

4. Council Directive 75/442, supra note 2 , art. 4.

5. Id. art. 7.

6. Id. art. 9.

7. Council Directive $78 / 319,1978$ O.J. (L 84) 43. This Directive will be replaced on Dec. 12, 1993 by Council Directive 91/689, 1991 O.J. (L 377) 20.

8. Council Directive 91/689, art. 2, 1991 O.J. (L 377) 20.

9. Id. art. 6.

10. Id. art. 2. 
- the Directive on the Disposal of Waste Oils (Directive 75/439,1 as amended by Directive $87 / 101^{12}$ ), requiring Member States to ensure the safe collection and disposal of waste oil and to maximize its recycling, ${ }^{13}$ and prohibiting certain discharges; ${ }^{14}$ and

- the Directive on the Supervision and Control Within the European Community of the Transfrontier Shipment of Hazardous Waste (Directive $84 / 631,{ }^{15}$ as amended by Directive $86 / 279{ }^{16}$ ), requiring notification of shipments, ${ }^{17}$ mandating acknowledgements, ${ }^{18}$ and allowing for objections and conditions. ${ }^{19}$

Second, general rules of the EEC Treaty are relevant in Member States' development of waste policies. In particular, the articles concerning the free movement of goods in the community (articles 30,34, and 36) ${ }^{20}$ and the articles on services (articles 59-65) ${ }^{21}$ are important.

Third, the European Court of Justice ${ }^{22}$ (the Court) has provided substantial new case law on the transportation of waste. ${ }^{23}$ The case law of the Court is particularly relevant because the Court has the final word in interpreting the law as it stands; in practice, therefore, case law has great precedential value.

EEC directives, the EEC Treaty, and EEC case law make the understanding of all of the legal aspects of EEC waste law a difficult task.

11. Council Directive 75/439, 1975 O.J. (L 194) 23.

12. Council Directive 87/101, 1987 O.J. (L 42) 43.

13. Id. art. 3.

14. Id. art. 4.

15. Council Directive 84/631, 1984 O.J. (L 326) 31 (to be replaced by Council Regulation 259/93, 1993 O.J. (L 30) 1 (implementing Basel Convention)).

16. Council Directive 86/279, 1986 O.J. (L 181) 13.

17. Id. art. 3.

18. Id.

19. Id. art. 4.

20. Article 30 prohibits quantitative restrictions on imports and all measures having equivalent effects. Article 34 prohibits quantitative restrictions on exports, and all measures having equivalent effects. Article 36 allows for restrictions on trade if they are necessary for human health or the protection of animals and plants. EEC TREATY arts. 30, 34, 36.

21. The articles on services require, for instance, that foreign waste disposal companies have non-discriminatory access to the national waste disposal market. See id. art. 65.

22. The Court was established by the Treaty of Paris. Treaty Establishing the Eu. Ropean Coal and STEel Community, art. 32, [ECSC TREaTY]. The Court is composed of 13 justices, one from each of the Member States, plus a rotating thirteenth justice. Id. It is solidly based on the civil law tradition and also serves as a lawmaker.

23. The most important cases are: Case $21 / 79$, Commission v. Italy, 1980 E.C.R. 1,2 C.M.L.R. 613 (1980); Case 172/82, Syndicat National des Fabricants Raffineurs v. InterHuiles, 1983 E.C.R. 555, 3 C.M.L.R. 485 (1983); Case 240/83, Procureur de la Republique v. ADBHU, 1985 E.C.R. 531; Case 239/85, Commission v. Belgium, 1986 E.C.R. 645, 1 C.M.L.R. 248 (1988); Case 372-374/85, Ministère Public v. Traen, 1987 E.C.R. 2141, 3 C.M.L.R. 511 (1987); Case 302/86, Commission v. Denmark, 1988 E.C.R. 4607, 1 C.M.L.R. 619 (1989) [Danish Bottle Case]; Case 380/87, Base v. Comune di Cinicello Balsamo, 1989 E.C.R. 2491, 1 C.M.L.R. 313 (1991); Joined Cases 206/88 \& 207/88m, Criminal Proceedings against Vessoso \& Zanetti, 1990 E.C.R. 1461. 
However, I will not attempt to discuss all the detail of this interesting field of law. Instead, this piece focuses on the following central question: does the EEC Treaty provide an adequate and suitable framework for regulating waste disposal and developing waste prevention policies? In particular, I will discuss some of the consequences of considering, in terms of the EEC Treaty, waste as a "good."24

IS WASTE A "GOOD"?

Recently, in Commission v. Belgium, the Court was faced with the critical question of whether waste is to be regarded as a "good" in the context of the EEC Treaty. ${ }^{25}$ Despite arguments that the Court should distinguish between recyclable and non-recyclable waste, the Court held that all waste had to be treated as a "good." The court reasoned that, from a practical point of view ("du point de vue pratique"), serious difficulties would arise, especially with respect to border control, if such a distinction were made. ${ }^{26}$ Such a distinction would also be based on uncertain characteristics-which, because of technical developments and the profitability of re-used waste, could be changed in time. Because of these factors, the Court found that all waste should be treated as a "good" under Article 30 of the EEC Treaty. ${ }^{27}$

II

APPLICATION OF EEC LAW TO GOODS

If waste is to be regarded as a "good"-as Commission v. Belgium appears to hold-several consequences will follow. Basically, regulation of waste transportation is subject to the same free trade restrictions as other goods.

First of all, the articles in the EEC Treaty become applicable. Article 30 prohibits quantitative restrictions on imports and all measures having equivalent effect between the Member States. ${ }^{28}$ Article 34 prohib-

24. In this article, I refer to the terms "good" and "product" interchangeably. This convention is commonly observed by other scholars and lawyers.

25. Case C-2/90, Commission v. Belgium, (July 9, 1992), available in LEXIS, INTNAT library, CJCS file. A summary of this case is available in Common Mkt. Rep. (CCH) \ 96,591 (Oct. 1992). There were also some earlier rulings by the Court which, in a more implicit manner, made it clear that waste falls under the normal rules of the free movement of goods within the EEC. See, e.g., Inter-Huiles, 1983 E.C.R. 555; ADBHU, 1985 E.C.R. 531.

26. Case C-2/90, Commission v. Belgium, opinion \ 27.

27. Id. at 15-16. Cf. Peter von Wilmowsky, Abfallwirtschaft im Binnenmarkt: Europäische Probleme UND AMERIKanisChe ERFAHrungen 161-63 (1990) (arguing that waste is distinguishable from goods, and that waste disposal falls under the rules concerning services as opposed to the rules concerning free movement of goods); Peter von Wilmowsky, Abfall ud reier Warenverkehr: Bestandsaufnahme nach dem EuGH-Urteil zum Wallonischen Einfuhrverbot, 1992 EUROPARECHT 414, 416.

28. EEC TREATY, art. 28. 
its quantitative restrictions on exports and all measures having equivalent effect. ${ }^{29}$

According to the ruling in the Dassonville case, article 30 covers all trading rules enacted by Member States that are capable of hindering, directly or indirectly, actually or potentially, intra-community trade. ${ }^{30}$ For the environmental sector, this includes import bans, import licensing systems, packaging and labelling obligations, user restrictions, and duties to notify.

We also must note that these rules on the free movement of goods are not only directed to national authorities, but also to the Commission and the Council. Unlike the United States, where the federal government may burden interstate commerce, ${ }^{31}$ the Council is bound by the provisions of articles 30, 34, and 36 of the Treaty-although experts are unsure whether these rules apply to the EEC institutions in exactly the same strict manner as they apply to the Member States. ${ }^{32}$ EEC policy and regulations, therefore, must meet, in principle, the requirements of those Treaty provisions.

A ruling on this important issue was made in the Inter-Huiles case. ${ }^{33}$ In that case, the Court held that article 34's prohibition includes (1) all national measures whose specific object or effect is to restrict patterns of exports and (2) the establishment of differing treatment between the domestic trade of a Member State and its export trade so as to provide a special advantage for domestic products. ${ }^{34}$ The Court also held that provisions of EEC directives which create these effects are similarly contrary to article $34 .^{35}$ EEC policies are thus restricted to the scope granted to the EEC institutions.

III

ENVIRONMENTAL JUSTIFICATIONS FOR LIMITS TO FREE TRADE

However, restrictions on trade can be justified if they are necessary for "the protection of health and life of humans, animals or plants" 36 or if they are necessary for the protection of the environment. ${ }^{37}$ In deter-

29. Id. art. 34 .

30. Case 8/74, Precureur du Roi v. Dassonville, 1974 E.C.R. 851, 852, 2 C.M.L.R. 436, 444 (1974). For a discussion of the Dassonville case and EEC articles 30-36, see LAURENCE W. Gormley, Prohibiting Restriction on Trade Within the EEC (1985); Peter OliVER, FREE MOVEMENT OF GOODS IN THE EEC (2d ed. 1988).

31. U.S. CONST. art. I, § 8, cl. 3.

32. See WILMOWSKY, supra note 27 (suggesting that the rules on the free movement of goods apply to Community institutions as well as Member States).

33. Inter-Huiles, 1983 E.C.R. 555.

34. Id. at 566.

35. Id.

36. EEC TREATY art. 36.

37. This environmental protection exception derives from the Danish Bottle Case, 1988 E.C.R. 4607. 
mining the extent of these justifications, the Court has generally used two limiting principles: proportionality and non-discrimination.

\section{A. Commission v. Belgium}

Commission v. Belgium ${ }^{38}$ is the most recent major case in this area. It has also set the stage by holding that waste is a "good." 39 For these reasons, it is important to take note of the Court's reasoning.

The Court was confronted with the Regional Executive of Wallonia's ${ }^{40}$ prohibition of the deposit in Wallonia of waste originating in other Member States. ${ }^{41}$ The Commission ${ }^{42}$ viewed Wallonia's action as incompatible with EEC law. The Court, in rendering its decision, did find the absolute restriction on hazardous waste trade to be incompatible with the system established by Directive 84/631, but the Court found the non-hazardous restriction-in the absence of any specific provision concerning the transportation of non-hazardous waste in Directive 75/442to be justified, under article 30 , because of the special character of waste. ${ }^{43}$

In analyzing Wallonia's prohibition, the Court first examined the measures in light of Directives $75 / 442$ and $84 / 631.44$

With respect to Directive $75 / 442$, the Court pointed out that neither the general framework of that Directive, nor any of its provisions, specifically covered waste trade between Member States. Nor did the Directive impose a prohibition on adopting measures such as those introduced by Wallonia. Therefore, there was no breach of Directive 75/442. ${ }^{45}$

Concerning Directive 84/631, the Court initially noted that the Directive introduced a system under which national authorities could raise objections to the transportation of hazardous waste and thus prohibit a specific transfrontier shipment. ${ }^{46}$ Thus, the Court held, the system im-

38. Case $\mathrm{C}-2 / 90$, Commission v. Belgium.

39. Id. at $15-16$.

40. Wallonia is one of three autonomous provinces in Belgium. Wallonia covers the southeast portion of the country and is French speaking. 1 Europa Publications, The EUROPA WORLD YEAR BOOK 1992, at $482-84$ (1992).

In European law, the federal or central government (i.e., Belgium) is liable for breaches of European law caused by the local or regional authorities (i.e., Wallonia). See, e.g., Joined Cases C-227-230/85, Commission v. Belgium, 1988 E.C.R. 1, 2 C.M.L.R. 797 (1989) (internal governmental difficulties not an adequate justification for Belgium's failure to implement environmental directives).

41. Case C-2/90, Commission v. Belgium.

42. The Commission's most important function is to draft all legislation. It also prosecutes all violations of EEC law, negotiates for the EEC, and administers the EEC's budget. 1 Europa Publications, supra note 40, at 146.

43. Case C-2/90, Commission v. Belgium, opinion II $20,35$.

44. Id. For a discussion of the directives, see supra text accompanying notes 2-6, 15-19.

45. Case C-2/90, Commission v. Belgium, opinion ff 14.

46. Id. It is important to note that Directive 84/631 only allows this prohibition in order to prevent problems related to environmental protection and public health and safety. Council 
plicitly did not allow Member States to completely prohibit such movements. Because the Belgian regulation imposed an absolute prohibition on the importation of hazardous waste into Wallonia, it did not comply with Directive 84/631.47

Next, on the issue of transportation of non-hazardous waste-which is not covered by directive $84 / 631$ - the Court examined the Wallonia legislation in light of articles 30 and 36 of the EEC Treaty. The Court decided that waste, recyclable or not, had to be treated as a product, the free movement of which, pursuant to article 30 of the Treaty, could not in principle be restricted. ${ }^{48}$

However, the Court also found that waste was a product with a special character: the simple accumulation of waste, even before it constituted a danger to health, represented a danger to the environment. The Court found this danger especially present in view of the limited capacity of each region or area to accommodate the storage of vast quantities of waste. Because of this special character, the Court found compelling Wallonia's argument that mandatory requirements of environmental protection justified the disputed measures. ${ }^{49}$

The Commission argued in response that these mandatory requirements for environmental protection and health and safety could not be relied on to allow Wallonia's restrictions. The Commission insisted that the measures at issue discriminated against waste coming from other Member States, though that waste was no more harmful than that produced in Wallonia. ${ }^{50}$ The same line of reasoning was developed by Advocate General Jacobs in his opinion. ${ }^{51}$ In the Advocate General's view, there was "plain" discrimination between foreign and Belgian waste and therefore the ruling of the Court in the Danish Bottle Case ${ }^{52}$ could not serve as precedent.

The Court, however, took a surprisingly new approach. The Court found it necessary to take into account the specific nature of the waste in determining whether the barrier in question was discriminatory. ${ }^{53}$ The proximity principle of the EEC Treaty ${ }^{54}$ - which states that environmen-

Directive 84/631, art. 4, 1984 O.J. (L 326) 31, 33, 34.

47. Case C-2/90, Commission v. Belgium, opinion ๆी 20-21.

48. Id. opinion \ 27.

49. Id. opinion ๆ 32.

so. Id. opinion I 33.

51. The Advocate General is a special lawyer who acts as a permanent amicus curiae for the EEC, and analyzes and evaluates all cases before the Court. There are six Advocates General appointed for six year terms. EEC TREATY arts. 166-67.

52. Danish Bottle Case, 1988 E.C.R. 4607.

53. Case C-2/90, Commission v. Belgium, opinion ๆ 34.

54. "Action by the Community relating to the environment shall be based on the principles that preventative action should be taken, that environmental damage should as a priority be rectified at source, and that the polluter should pay. Environmental protection requirements shall be a component of the Community's other policies." EEC TREATY art. 130R(2) 
tal damage should as a priority be rectified at its source-implied that it was incumbent on each region, community, or other local authority to take the measures appropriate to ensure the proper reception, treatment, and disposal of its own waste. Such waste, therefore, had to be disposed of as close as possible to the place of its production in order to minimize its transportation. ${ }^{35}$

The Court held that the proximity principle was consistent with the principles set out in the Basel Convention on the Control of Transboundary Movements of Hazardous Waste and Disposal, ${ }^{56}$ a convention to which the EEC was a signatory. ${ }^{57}$ The Court came to the following conclusion: in view of the differences between waste produced in one place and that produced in another, and in view of the waste's connection with the place where it was produced, the Belgian measures could not be considered discriminatory. ${ }^{58}$

\section{B. Proportionality}

In relying on environmental justifications for interferences with trade, Member States must first observe the "principle of proportionality": the aim of protecting the environment, or the health and life of humans, animals, and plants, must be achieved by the means least restrictive of intra-Community trade. ${ }^{59}$ The Court always examines whether the contested rules are really necessary to achieve the rules' objectives. In Commission v. Belgium, however, the Court did not examine whether Wallonia's import bans met the requirements of this prin-

(as amended 1987) (emphasis added).

55. Case C-2/90, Commission v. Belgium. If the nearest waste disposal installation is in another country, there can be a tension between the "self sufficiency principle" and the "proximity principle" - with respect to both exports and imports. See Directive $75 / 442$, supra note 2 , art. 5 (delegating authority for planning, organization, authorization, and supervision of waste disposal operations).

56. Case C-2/90, Commission v. Belgium, opinion If 35. Basel Convention on the Control of Transboundary Movements of Hazardous Waste, March 22, 1989, 28 I.L.M. 649 (1989) [hereinafter Basel Convention]. For a comparison of the Basel Convention directives with the EC directives, see Stephen B. Straske II, The United Nations Basel Convention on the Control of Transboundary Movements of Hazardous Wastes and Their Disposal, 3 GEo. INT'L ENVTL. L. REV. 183 (1990).

57. The EEC has not yet ratified this convention, partly because Directive $84 / 631$ must be amended so that it is consistent with the Convention. There is a certain amount of consensus on the changes that need to occur in Directive 84/631 and that ratification of the Convention should follow that amendment. See supra note 15.

58. Case C.2/90, Commission v. Belgium, opinion \ 36 .

59. See, e.g., $A D B H U, 1985$ E.C.R. at 549 (finding that the directive providing means by which Member States may dispose of waste oil does not restrict trade in violation of Community law principles); Danish Bottle Case, 1988 E.C.R. at 4629 (Danish legislation requiring use of returnable containers was more restrictive of imports than necessary). The principle of proportionality can be traced back to Case $7 / 68$, Commission v. Italian Republic, 1968 E.C.R. $423,430$. 
ciple. This seems like a remarkable omission, bringing into doubt the Court's reasoning.

\section{Non-Discrimination}

Another important element to be observed by Member States relying on environmental justifications is the rule of non-discrimination: measures protecting the environment must be applicable to both domestic and imported products, without distinction. Article 36 of the EEC Treaty states this in somewhat different language, leaving the Member States some room for differentiation: Restrictions on trade "shall . . . not constitute a means of arbitrary discrimination or disguised restriction on trade between Member States."60 However, in the Wallonia case, the Court seemed to limit the significance of this principle, holding that waste has a special character and that legislation can discriminate between domestic and foreign waste. ${ }^{61}$

\section{IV \\ PROXIMITY}

Perhaps the primary guiding value in European waste disposal policy is the "proximity principle."62 It is now official EEC policy that waste should be disposed of at the nearest appropriate installation. According to the new article 5 of the framework Directive 75/442, Member States are obliged

to establish an integrated and adequate network of disposal installations, taking account of the best available technology not involving excessive costs. The network must enable the Community as a whole to become self-sufficient in waste disposal and the Member States to move towards that aim individually, taking into account geographical circumstances or the need for specialized installations for certain types of waste. The network must also enable waste to be disposed of in one of the nearest appropriate installations, by means of the most appropriate methods and technologies in order to ensure a high level of protection for the environment and public health. ${ }^{63}$

The problem with the proximity principle is that the nearest installation will generally be in the same country as where the waste is produced. It is more or less a disguised "self-sufficiency principle." However, the nearest waste disposal facility may not operate under the soundest environmental conditions. The proximity principle would then contradict the proportionality requirements, as well as the ethos of environmental protection and the general rules in the EEC Treaty concerning

60. EEC TREATY art. 36.

61. Case C-2/90, Commission v. Belgium, opinion If 34-36.

62. Id.

63. See Council Directive 91/156, art. 5, 1991 O.J. (L 78) 34. 
the free movement of goods. ${ }^{64}$ This seems to be the flaw in the Court's reasoning in the Wallonia case.

The Basel Convention on the import and export of dangerous waste also mandates that states should dispose of their waste in their own country. ${ }^{65}$ It states that there should be no free movement of waste, unless there are environmental reasons to decide otherwise. Although this apparently contradicts the EEC Treaty, which states that there should be free movement of goods, including waste, unless there is an environmental reason to restrict trade, ${ }^{66}$ the Court does not view the two treaties as contradictory. ${ }^{67}$

\section{$\mathrm{V}$ \\ PROFITABILITY JUSTIFICATIONS}

One of the reasons for Member States to prohibit the export of waste is to ensure that their own national waste disposal installations can operate profitably. There is always the danger that, as a result of the export of large quantities of waste, the capacity of national disposal installations will be greater than the demand for waste disposal. This can result in underutilized national waste disposal capacity, inflated prices of waste disposal, and the creation of even more waste exports. To avoid this, some Member States want to restrict the export of waste, improving the supply for their own national disposal installations.

A fine example of this can be found in the Inter-Huiles case. ${ }^{68}$ According to French law, all waste oil must be delivered to officially authorized waste oil collectors. ${ }^{69}$ By implication, this legislation prohibited the export of waste oils to foreign countries, including other Member States, because they were not authorized. The French Government argued that the disputed legislation satisfied an economic requirement, since only the collection of all waste oils sufficiently ensured the profitability of approved waste oil undertakings. ${ }^{70}$ The Court rejected this argument. It found that the waste oil directive required Member States to grant indemnities to such undertakings-financed according to the "polluter pays" principle-instead of establishing export restrictions. ${ }^{71}$

A similar decision can be found in the Nertsvoederfabrick case. ${ }^{72}$ A Dutch law required poultry offal to be delivered only to licensed render-

64. EEC TREATY art. 30.

65. Basel Convention, supra note 56, art. 4, sec. 2(d), 28 I.L.M. at 662.

66. EEC TREATY art. 130.

67. Case C-2/90, Commission v. Belgium, opinion \ 36.

68. Inter-Huiles, 1983 E.C.R. 555.

69. Id. at 564.

70. Id. at 566.

71. Id.

72. Case 118/86, Openbar Ministrie v. Nertsvoederfabrick, 1987 E.C.R. 3883. 
ing plants. ${ }^{73}$ This law implied a prohibition of exports as well. The Netherlands government argued that the law was essential to maintain the overall effectiveness of the Dutch system. ${ }^{74}$ With respect to the export restrictions only, the Court held that these were not necessary and therefore incompatible with article 34 of the EEC Treaty. ${ }^{75}$

On the other hand, Directive 84/631 on the import and export of hazardous waste states that Member States may raise objections to the export of waste on the grounds that the shipment of waste adversely affects the implementation of their waste disposal plans. ${ }^{76}$

In conclusion, it is still uncertain to what extent EEC law allows Member States to restrict the export of waste to ensure the profitability of their national waste disposal installations. This is so because there is a conflict between case law and the directives. The Court, in the InterHuiles case and the Nertsvoederfabrick case, suggests that these restrictions are not allowed, but the new framework directive on waste ${ }^{77}$ and the import/export directive ${ }^{78}$ seem to point in the opposite direction.

VI

EXTRATERRITORIAL PROTECTION JUSTIFICATIONS

Another legal problem not yet fully resolved in EEC law is the question of extraterritorial environmental responsibilities for the export of waste. Can a Member State refuse to export waste on the grounds that the manner of waste disposal in the import state does not comply with the standards of the export state? The Basel Convention explicitly warrants this sort of regulation. ${ }^{79}$

With respect to waste oils, this question was decided in the InterHuiles case. The French Government refused to allow the export of waste oil in part because it feared environmental damage in Belgium. The Court, however, rejected this argument. The Court reasoned as follows: "Clearly, the environment is protected just as effectively when the

73. Id. at 3884 (citing Netherlands Destructiewet (law on the destruction of cattle carcasses and animal offal) of 21 Feb. 1957, Stb. 1975/84).

74. Id. at 3889.

75. Id. at 3909 . The Court did not make any rulings with regard to imports.

76. Council Directive $84 / 631$, supra note 15 , art. $4, \S 6$.

77. Council Directive $75 / 442$, supra note 2 .

78. Council Directive 84/631, supra note 15.

79. Each party shall require that hazardous wastes or other wastes, to be exported, are managed in an environmentally sound manner in the State of import or elsewhere. Technical guidelines for the environmentally sound management of wastes subject to this Convention shall be decided by the Parties at their first meeting.

Basel Convention, supra note 56, art. 4(8), 28 I.L.M. at 663.

In the Netherlands, for example, no export of hazardous waste is allowed where the standards of the recipient state do not meet Dutch standards. Decision of the "Voorzitter van de Afdeling Geschillen van de Raad van State" (Chairman of the Public Disputes Division of the Council of State) 23 March 1989, Sociall Economische Wetgeving 36-40 (1989). 
oils are sold to an authorized disposal or regenerating undertaking of another Member State as when they are disposed of in the Member State of origin." 80 Because the directive on waste oils harmonized national laws, ${ }^{81}$ there was no real necessity for extraterritorial action. Additionally, the directive on import and export does not allow the exporting state to intervene on behalf of the environment of the importing state. The import state exclusively is empowered to assess the environmental consequences within its jurisdiction. ${ }^{82}$

The Court, however, did not decide to what extent a Member State may restrict the export of waste oils to states outside the EEC, where the directive on waste oils is not applicable. In this regard, the exporting state has the responsibility to see that no export takes place unless it has ensured that the importing state has the technical capacity to dispose of the waste properly, so there is reduced danger to human health or the environment. ${ }^{83}$ Within the framework of the Lome Convention ${ }^{84}$ (which applies to the former colonies of the Member States) the responsibility goes even further. Article 39 of the Lome Convention prohibits the export of hazardous and nuclear waste to those states. ${ }^{85}$

\section{CONCLUSION}

The cornerstone of the EEC Treaty is the free movement of goods, including environmentally dangerous or hazardous goods. According to the EEC Treaty, restrictions on trade may be allowed if they are necessary to protect the environment. However, these trade restrictions may not go beyond those proportionally necessary. They may not discriminate between domestic and foreign waste. Also, as emphasized in Commission $v$. Belgium, ${ }^{86}$ the proximity principle-and to some extent the self-sufficiency principle-require that waste be disposed of locally.

Some uncertainty remains, however. Legal uncertainty exists with respect to whether export restrictions for waste are allowed to ensure the profitability of national waste disposal installations. And another question still in doubt is whether extraterritorial responsibility for preventing environmental damage can restrict the trade of waste.

At the beginning of this paper, I asked if the EEC Treaty provides a suitable framework for an environmentally sound waste disposal policy. Commission v. Belgium has given me some hope for the use of environmental justifications, and for the use of the proximity and self-sufficiency

80. Inter-Huiles, 1983 E.C.R. at 566.

81. Council Directive 75/439, supra note 11 , art. 17.

82. See Council Directive 84/631, supra note 15 , art. 4.

83. Id.

84. Fourth ACP-EEC Convention of Lome, Dec. 15, 1989, 29 I.L.M. 783.

85. Id. art. 39, 29 I.L.M. at 819.

86. Case C-2/90, Commission v. Belgium, at 17. 
principles, to develop a sound waste disposal policy. The decision also makes clear that the Basel Convention is not problematic. Aside from profitability and extraterritorial concerns, which may in some cases be actually quite important, it does seem that the EEC has developed, with the aid of the Court, a suitable framework for waste disposal policy. 